\title{
Studies on farmland woody species diversity and their socioeconomic importance in Northwestern Ethiopia
}

\section{Kidane Giday, Fekadu Debebe, Antony Joseph Raj* and Destaalem Gebremeskel}

Department of Land Resource Management and Environmental Protection, College of Dryland Agriculture and Natural Resources, Mekelle University, P.O. Box 231, Mekelle, Tigray, Ethiopia

*Corresponding Author: drajr.aaidu@gmail.com

[Accepted: 30 July 2019]

\begin{abstract}
Study was conducted in the farmlands of Northwestern Ethiopia with the objective of assessing woody species diversity and their socioeconomic importance. Three sites representing three different elevations viz. highland, midland and lowland agroecology were selected. A total of 196 households were randomly selected to collect socioeconomic data. Data on woody species diversity in crop fields was collected by categorizing households as rich, medium and poor and from that categorized household the woody species data were collected from near, medium and far away from homesteads. A total of 39 woody species belonging to 24 families were recorded in the farmlands of the study area. The Shannon diversity index varied from 2.61 to 2.85 and species evenness varied from 0.83 to 0.87 in the study areas. Woody species diversity, richness and abundance were significantly different between rich, medium and poor households at the three study sites. Similarly species richness, abundance and diversity were significantly different among near, medium and far distance farmlands from homesteads. According to the respondents, the main purposes of retaining or planting woody species on their farmland were for soil fertility (35.14\%), firewood $(24.54 \%)$, timber production $(11.66 \%)$, fencing $(8.44 \%)$, animal fodder $(4.55 \%)$, fruit $(4.50 \%)$, income generation $(4.28 \%)$, house construction $(2.61 \%)$, charcoal production $(1.61 \%)$ and other purposes. Retaining or planting woody species on farmlands significantly contributed for the conservation of biodiversity in the study area.
\end{abstract}

Keywords: Woody species diversity - Shannon diversity index - Species richness - Species evenness - Species abundance.

[Cite as: Giday K, Debebe F, Raj AJ \& Gebremeskel D (2019) Studies on farmland woody species diversity and their socioeconomic importance in Northwestern Ethiopia. Tropical Plant Research 6(2): 241-249]

\section{INTRODUCTION}

Agriculture is not only the main cornerstone of the economy, but also the major occupation of Ethiopian population (MoME 2003). Rapid population growth and the long history of sedentary agriculture have changed the land use/land cover systems and caused environmental degradation in many developing countries including Ethiopia (Zerihun 2002). Asfaw (2010) reported that population growth and environmental degradation lead to loss of forest area, habitat fragmentation, land degradation, and biodiversity losses. Across tropical Africa, approximately $21.7 \%$ of forests have been deforested since 1900 and West \& East African forest areas have undergone almost complete decline (Aleman et al. 2018). Deforestation is a significant challenge across mountainous areas of sub-Saharan Africa, particularly in the Ethiopian highlands. At the beginning of the twentieth century $35 \%$ of Ethiopia's land was covered by trees but recent FAO (2010) report indicates that Ethiopia's forest cover is 12.296 million ha which is $11 \%$ of the total land area. The FAO (2011) estimated a deforestation rate of $1,410 \mathrm{~km}^{2}$ per year in Ethiopia with an annual deforestation rate of $1.1 \%$. The economic loss of genetic resource due to deforestation in Ethiopia ranges between 0.4 and 1.5 billion USD per year (Srinivasan 2014). In the Amhara region of northern Ethiopia, average landholdings of farming families have gone down to less than 1 ha per family, driving the rapid conversion of forests, woodlands, and shrublands to crop fields and treeless rangeland (Mengistu \& Hager 2010). Loss of woody plant diversity poses a clear risk to the wellbeing of subsistence farming communities (Teketay 2001). 
To reduce existing pressure on remaining forests and keep the valuable products \& ecosystem services provided by woody plants, many local communities are renewing efforts to retain or plant useful trees and shrubs within croplands, grazing areas, and other portions of their landscapes. These exercises can increase the availability of intellectual nourishment, health, and energy resources to raising families, diversify opportunities for income generation, and thereby optimize the productivity, stability, and resilience of farming systems (Hoekstra et al. 1990). Furthermore, planting and protecting trees and bushes can help to reverse deforestation while offsetting the socioeconomic impacts of land scarcity, because farming families are able to develop multiple products from their relatively small landholdings.

To rehabilitate the degradation of land, small-holder farmers throughout the world deliberately retain trees and shrubs on land that is used for cropping. Scope of roles woody plants play in traditional agriculture systems have been identified by many researchers (Mekonnen 2001, Negash 2007, Neba 2009, Alemayehu \& Hager 2010, Tabuti 2012). Farmers protect, plant, and encourage woody species within and around their gardens, crop fields, and communal pasture lands to derive a range of benefits, including provisions of food, fodder, construction textiles, farm equipment, fuel wood, and medicines as an agroforestry practice. The integration of trees, agricultural crops, and/or animals in an agroforestry system has the potential to enhance soil fertility, reduce erosion, better water quality, enhance biodiversity, increase aesthetics, and sequester carbon (Jose 2009). The retention of trees and shrubs in agricultural landscapes depends on local ecological knowledge regarding the use and conservation of species, the values of plants within subsistence and market economic systems, soil and other resource tenure systems that limit access, spiritual feelings and traditions associated with plants, as well as changes in sociocultural structures (Neba 2009).

In Northwestern Ethiopia, research works and information on farmland woody species diversity and their socioeconomic importance are very limited. The main reason is that less attention has been given for the practice of retaining or planting woody vegetation on farms, so measurement of woody species diversity in farmlands will give a clear picture on biodiversity conservation status. The present study was conducted at Jabitehinan district, northwestern Ethiopia with the objective to assess the diversity of woody species and the purpose of maintaining woody species in farmlands.

\section{MATERIALS AND METHODS}

Study site

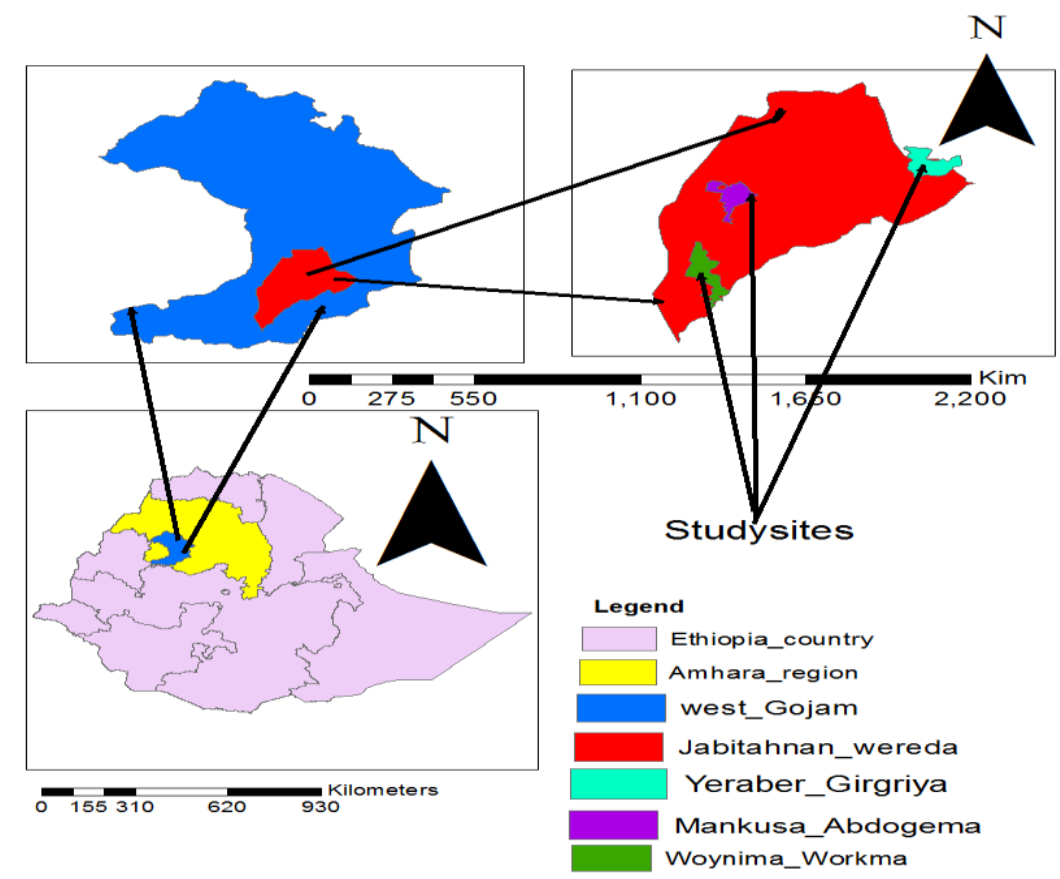

Figure 1. Map of the study area.

The study was conducted in Jabitehnan district, West Gojjam Zone of Amhara National Regional State, Ethiopia (Fig. 1) and geographically it is found between $10^{\circ} 40^{\prime}$ to $10^{\circ} 45^{\prime}$ latitude and $37^{\circ} 11^{\prime}$ to $37^{\circ} 13^{\prime}$ east longitude. Jabitehinan district was selected by purposive sampling because of the presence of more agroforestry potential. The mean annual temperature is about $23^{\circ} \mathrm{C}$, with maximum temperature slightly above $32^{\circ} \mathrm{C}$ and minimum temperature of $14^{\circ} \mathrm{C}$. The mean annual rainfall ranges between $800-1250 \mathrm{~mm}$ (JWARDO 2016). The 
topography of the district is generally characterized by flat-gentle slope (65\%), mountainous (15\%), undulating terrain (15\%), and valley (5\%), with an altitudinal rage from 800-2300 m.a.s.l. The major soil types found in the district are vertisols and Nitisols (JWARDO 2016). Based on the 2007 national census conducted by central statistical agency, this District has a total population of 277,590 , of whom 139,616 individuals are males and 137,974 are females.

Agriculture is the principal source of livelihood for the rural population. It is characterized by subsistence mixed farming of rain-fed, irrigated crops and livestock. The dominant crops are maize, teff, and millet. Besides the crop plants, the common woody vegetation in the district includes tree species of Croton macrostachyus Hochst. ex Delile, Ficus sur Forssk., Ficus vasta Forssk., Albizia gummifera (J.F. Gmel.) C.A. Sm., Cordia Africana Lam., Acacia abyssinica Hochst. ex Benth., Rosa abyssinica Lindley, and Erythrina abyssinica Lam. ex DC. which are found as scattered in most landforms, whereas Eucalyptus spp. and Grevillea robusta A. Cunn. ex R. Br. are grown as boundaries, live fences and woodlots (JWARDO 2016).

Stratified random sampling design was followed in the present research. First the Jabitehnan district was divided into different agroecology based on elevation, viz. highland, midland and lowland and the following villages were selected randomly from each agroecology, Yeraber Girgriya (2,500-2,800 m.a.s.l) from highland, Mankusa Abdogema (1,500-2,000 m.a.s.1) from midland and Woynima Workima (less than 1,500 m.a.s.l) from lowland.

\section{Key informants selection and household survey}

Total of 15 key informants (KIs) were selected from the study area (five KIs each from the three selected villages) by snowball method. At least four farmers were asked to identify and give names of five key informants from each study sites as defined above. The purpose of selecting KIs was to categorize villagers by wealth categories and to provide information on agroforestry management and historical development of onfarm trees. To characterize households ( $\mathrm{HHs}$ ) in each village into different social classes, wealth ranking was carried out by adopting the technique used by Crowley (1997). Key informants were used to categorize/classify all individual HH's in each selected villages into three main wealth categories (rich, medium, poor) based on the criteria of farm size, number of cattle (particularly number of oxen and cows), availability of house etc. From the wealth classes, distances of the farm plot were identified as near, medium and far from their residence during data collection.

Finally, 196 households (HHs) were selected (Table 1) randomly to assess woody species diversity and their importance. The sample size in the village was selected based on the formula of Kothari (2004) as given below so as to avoid the bias.

$$
\mathrm{n}=\mathrm{Z}^{2} \mathrm{PQN} / \mathrm{E}^{2}(\mathrm{~N}-1)+\mathrm{Z}^{2} \mathrm{PQ}
$$

Where, $\mathrm{n}=$ Sample size; $\mathrm{N}=$ Number of house hold; $\mathrm{P}=$ Level of precision which is $5 \%=0.05$; $\mathrm{E}=$ Allowed error which is $5 \%=0.05 ; \mathrm{Q}=1-\mathrm{P}=1-0.05=0.95 ; \mathrm{Z}=$ Confident interval 95\%, 1.96 from $\mathrm{Z}$-table.

Table 1. The number of selected households in the study villages.

\begin{tabular}{|c|c|c|c|}
\hline Name of Village & & Household Size & $\begin{array}{r}\text { Households surveyed for socio-economic } \\
\text { baseline and diversity }\end{array}$ \\
\hline Yeraber Girgriya & & 643 & $\begin{array}{ll}+65 \\
\end{array}$ \\
\hline Mankusa Abdogema & & 718 & 66 \\
\hline Woynima Workima & & 556 & 65 \\
\hline & Total & 1907 & 196 \\
\hline
\end{tabular}

Data on socioeconomic uses of woody species were collected through interview using semi-structured questionnaire and focus group discussions on 196 households. Secondary information pertinent to the study areas was collected from previous studies, organizations (District Office of Bureau of Agriculture) and other published sources.

Woody species inventory

All the woody species in each household's farmland $\geq 5 \mathrm{~cm}$ DBH were identified and measured. Plant with height less than $1.5 \mathrm{~m}$ was considered as seedling while height between 1.5 and $3 \mathrm{~m}$ was taken as sapling and height greater than $3 \mathrm{~m}$ was taken as tree (Feyera et al. 2002). In the field, the identities of almost all species were recorded (using their vernacular name) with the help of the elder people. When identification was difficult in the field, vernacular names were recorded and identification was carried out using Flora of Ethiopia and Eritrea (Hedberg et al. 2003). From each HH wealth classes (rich, medium and poor) woody species data were collected from near, medium and far farm fields from HHs residence. 
Measurement of species richness and diversity

The sum of all species encountered in each study area (through counting the total number of species) was used to determine the species richness of the study area. Based on the individuals recorded in the study area, vegetation data were quantitatively analyzed for species abundance.

$$
\text { Abundance }=\frac{\text { Total number of Individual s of the species }}{\text { Total number of study areas of occurrence }}
$$

The species diversity was determined using the Shannon-Weiner diversity index $\left(H^{\prime}\right)$ according to the formula of Shannon \& Weiner (1963):

$$
\text { Shannon - Weiner Diversity Index }\left(H^{\prime}\right)=-\sum_{i=1}^{s}\left(P_{i}\right)(\log P i)
$$

Where, $\mathrm{s}=$ number of species; $P_{i}=$ proportion of species $i$ in the community

The Evenness or Equitability (J) was quantified by expressing Shannon index using the formula (Pielou 1966):

$$
\text { Species Evenness }(\mathrm{J})=\frac{H^{\prime}}{\log (S)}
$$

Where, $H^{\prime}=$ Shannon's diversity index; $\mathrm{S}=$ Number of species pooled in all study site

\section{Data analysis}

Descriptive statistics such as mean, percentages range and standard deviations were used for survey data. In the case of the woody species inventory, all data analysis were performed using SPSS version 16. One-way ANOVA was used. Significant differences detected through ANOVA with $\mathrm{P} \leq 0.05$ were investigated by comparison of means using Tukey's HSD test.

\section{RESULTS AND DISCUSSION}

Woody species richness, abundance, and diversity

A total of 39 woody species belonging to 24 families were recorded in the farmlands of the study area. The woody species richness recorded from the three study areas were 21, 26 and 25 species at Woynima Workima, Mankusa Abdogema and Yeraber Girgriya respectively (Table 2). From the total 1179 individuals recorded in the study areas, maximum species abundance of 416 was found at Mankusa Abdogema (Table 2). The similar high species richness and abundance in farmlands were reported in Blue Nile Basin of Ethiopia by Aklilu et al. (2013); on parkland agroforestry in central rift valley of Ethiopia by Asfaw (2016). Mahari (2014) reported that tree species in farmlands play a great role in maintaining soil fertility and provide various products and services to the local farmers. Similarly, farmers in the study area often consider these tree species can improve the fertility status of their soils because they observed that their abscised leaves are easily decomposable compared to the other available tree species. Guyassa et al. (2014) reported species richness of 21 indigenous fruit and fodder trees/shrub species in croplands of Northern Ethiopia.

Table 2. Overall diversity indices of woody species in study areas.

\begin{tabular}{lrrrr}
\hline Study Areas & $\begin{array}{r}\text { Shannon } \\
\text { diversity }\end{array}$ & $\begin{array}{r}\text { Species } \\
\text { evenness }\end{array}$ & $\begin{array}{r}\text { Species } \\
\text { abundance }\end{array}$ & $\begin{array}{r}\text { Species } \\
\text { richness }\end{array}$ \\
\hline Woynima Workima & 2.61 & 0.86 & 391 & 21 \\
Mankusa-Abdogema & 2.85 & 0.87 & 416 & 26 \\
Yeraber Girgriya & 2.67 & 0.83 & 372 & 25 \\
\hline
\end{tabular}

The Shannon diversity index varied from 2.61 to 2.85 and species evenness varied from 0.83 to 0.87 in the study areas. The highest species abundance (416) was recorded in Mankusa-Abdogema followed by Woynima Workima (391) (Table 2). As shown in table 2, the highest species diversity was recorded at Mankusa Abdogema village and this is due to the highest species richness in the study sites. This could happen because Shannon diversity index is usually associated with an increase in species richness (Tesfay et al. 2010). Guyassa et al. (2014) reported good woody species diversity index of 2.32 in croplands of Northern Ethiopia which indicated the farmers are actively integrating woody species in the farm. On the contrary, species evenness did not show significant difference among the study areas.

Effect of wealth status on woody species diversity and evenness

Woody species diversity for rich household was significantly higher than medium and poor households but woody species evenness did not show significant difference among rich, medium and poor households (Table www.tropicalplantresearch.com 
3). The reason for higher woody species diversity for rich household is due to the fact that rich households have large farm size than medium and poor households since farm size is one indicator of wealth status of household. This is because farmers who have small farm size concentrate on fewer species with great utility. Aklilu et al. (2013) stated that wealth status of farmers is highly correlated with farm size. Household wealth status influenced species diversity in the study sites. These findings are in agreement with Jarvis et al. (2000) and Kindt et al. (2004) who showed that wealth is an important socioeconomic factor influencing on farm tree diversity and farmer choices of crop varieties respectively. On the contrary, Boffa et al. (2008) stated that wealth status did not influence either the on-farm abundance or diversity of tree species around Mabira Forest reserve, Uganda.

Table 3. Mean Shannon diversity and species evenness of woody species among three wealth categories.

\begin{tabular}{llrrr}
\hline Indices & Wealth & Woynima Workima & Mankusa Abdogema & Yeraber Girgriya \\
\hline Shannon & Rich & $1.55^{\mathrm{a}} \pm 0.35$ & $1.53^{\mathrm{a}} \pm 0.34$ & $1.58^{\mathrm{a}} \pm 0.29$ \\
Diversity & Medium & $1.27^{\mathrm{b}} \pm 0.34$ & $1.37^{\mathrm{a}} \pm 0.35$ & $1.32^{\mathrm{b}} \pm 0.32$ \\
& Poor & $0.86^{\mathrm{c}} \pm 0.40$ & $0.99^{\mathrm{b}} \pm 0.38$ & $0.82^{\mathrm{c}} \pm 0.34$ \\
& Overall mean & $1.22 \pm 0.36$ & $1.29 \pm 0.35$ & $1.24 \pm 0.32$ \\
& & $\mathrm{P}<0.001, \mathrm{~F}=18.78$ & $\mathrm{P}<0.001, \mathrm{~F}=12.46$ & $\mathrm{P}<0.001, \mathrm{~F}=31.52$ \\
Species & Rich & $0.96^{\mathrm{d}} \pm 0.04$ & $0.94^{\mathrm{c}} \pm 0.05$ & $0.94^{\mathrm{e}} \pm 0.06$ \\
Evenness & Medium & $0.94^{\mathrm{d}} \pm 0.06$ & $0.95^{\mathrm{c}} \pm 0.09$ & $0.95^{\mathrm{e}} \pm 0.05$ \\
& Poor & $0.93^{\mathrm{d}} \pm 0.14$ & $0.92^{\mathrm{c}} \pm 0.22$ & $0.86^{\mathrm{e}} \pm 0.02$ \\
& Overall mean & $0.94 \pm 0.08$ & $0.93 \pm 0.12$ & $0.92 \pm 0.04$ \\
& & $\mathrm{P}=0.32, \mathrm{~F}=1.15$ & $\mathrm{P}=0.79, \mathrm{~F}=0.23$ & $\mathrm{P}=0.2, \mathrm{~F}=1.65$ \\
\hline
\end{tabular}

Note: Single different letters on mean values in one column indicates that there is significance difference at $(\mathrm{p}<0.05)$ between wealth classes whereas single similar letters in one column indicates that non-significant difference at $(p$ $>0.05)$.

\section{Effect of wealth status on woody species richness and abundance}

Woody species richness for rich household were higher than medium and poor households (Table 4). The finding of this study is in line with Aklilu et al. (2013) who stated that tree species richness increases as farm size increases. Asfaw \& Hulten (2003) and Abebe (2005) also reported a positive relationship between farm size and tree species richness per farm and a similar relationship between wealth status and farm size in southern Ethiopia. Jarvis et al. (2000) and Kindt et al. (2004) also reported that wealth status affects woody species abundance and richness. Species abundance is function of either household preference or best fit to the ecology or climate. The woody species abundance in the farmlands of rich household is significantly higher than medium and poor households (Table 4). This is because of rich households have more income and large farm size than medium and poor households. Present finding is supported by Alemu (2009) and Zebene et al. (2010) who found those households with relatively higher income, and a higher amount of off- farm income, are more likely to plant trees in northern Ethiopia.

Table 4. Mean species richness and abundance of woody species among the three wealth categories.

\begin{tabular}{llrrr}
\hline & Wealth & $\begin{array}{r}\text { Woynima } \\
\text { Workima }\end{array}$ & $\begin{array}{r}\text { Mankusa Abdogema } \\
\text { Yeraber } \\
\text { Girgriya }\end{array}$ & $\begin{array}{r}\text { Aand } \\
\text { Species }\end{array}$ \\
Richness & Rich & $5.38^{\mathrm{a}} \pm 1.83$ & $5.38^{\mathrm{a}} \pm 1.89$ & $4.95^{\mathrm{a}} \pm 2.22$ \\
& Medium & $4.19^{\mathrm{a}} \pm 1.89$ & $4.52^{\mathrm{a}} \pm 1.67$ & $3.29^{\mathrm{b}} \pm 1.52$ \\
& Poor & $2.81^{\mathrm{b}} \pm 1.08$ & $3.42^{\mathrm{b}} \pm 0.94$ & $2.52^{\mathrm{b}} \pm 0.98$ \\
& Overall mean & $4.13 \pm 1.60$ & $4.44 \pm 1.50$ & $3.58 \pm 1.57$ \\
Species & Rich & $\mathrm{P}<0.001, \mathrm{~F}=12.92$ & $\mathrm{P}<0.001, \mathrm{~F}=9.64$ & $\mathrm{P}<0.001, \mathrm{~F}=11.81$ \\
Abundance & Medium & $9.19^{\mathrm{a}} \pm 4.98$ & $9.62^{\mathrm{a}} \pm 5.09$ & $6.85^{\mathrm{a}} \pm 3.71$ \\
& Poor & $5.90^{\mathrm{b}} \pm 3.02$ & $6.00^{\mathrm{b}} \pm 2.81$ & $4.10^{\mathrm{b}} \pm 2.23$ \\
& Overall mean & $3.57^{\mathrm{b}} \pm 1.33$ & $4.10^{\mathrm{b}} \pm 1.51$ & $3.19^{\mathrm{b}} \pm 2.16$ \\
& & $6.22 \pm 3.11$ & $6.57 \pm 3.13$ & $4.71 \pm 2.7$ \\
\hline
\end{tabular}

Note: Single difference letters in one column indicates that there is a significant difference on the mean value of richness and abundance whereas similar letters indicates that non-significant difference at ( $\mathrm{p}>0.05)$.

Effect of distance of farmland from homesteads on woody species diversity and evenness

Farmers in the study areas retain trees according to the available space, compatibility with agricultural crops and household objectives. In the study sites, they retained and planted different woody species on farmlands near and far away from their homesteads. In the three study areas, woody species diversity for near distance farm plots to homestead was higher than from medium \& far distance farm plots but woody species evenness did not show significant difference among three distance categories (Table 5). The higher woody species 
diversity for near distance farm plots to homestead is due to the fact that woody species near to house is well managed and planted by farmers and also the higher soil fertility from animal manure which contribute to the higher performance of trees and shrubs. This result is confirmed by the finding of Felix et al. (2018) who reported that the higher soil fertility from animal manure around homesteads contributes the higher performance of trees and shrubs and also the daily follow up by farmers (Abebe et al. 2014).

Table 5. Mean Shannon diversity and species evenness of woody species among three distance categories from household's residence.

\begin{tabular}{llrrr}
\hline Indices & Distance & $\begin{array}{r}\text { Woynima } \\
\text { Workima }\end{array}$ & Mankusa Abdogema & $\begin{array}{r}\text { Yeraber } \\
\text { Girgriya }\end{array}$ \\
\hline Shannon & Near & $1.54^{\mathrm{a}} \pm 0.34$ & $1.62^{\mathrm{a}} \pm 0.32$ & $1.48^{\mathrm{a}} \pm 0.40$ \\
Diversity & Medium & $1.19^{\mathrm{b}} \pm 0.47$ & $1.32^{\mathrm{b}} \pm 0.28$ & $1.27^{\mathrm{a}} \pm 0.39$ \\
& Far & $0.95^{\mathrm{b}} \pm 0.35$ & $0.94^{\mathrm{c}} \pm 0.35$ & $0.96^{\mathrm{b}} \pm 0.38$ \\
& Overall mean & $1.22 \pm 0.38$ & $1.29 \pm 0.31$ & $1.24 \pm 0.39$ \\
& & $\mathrm{P}<0.001, \mathrm{~F}=11.94$ & $\mathrm{P}<0.001, \mathrm{~F}=23.52$ & $\mathrm{P}<0.001, \mathrm{~F}=9.78$ \\
Species & Near & $0.94^{\mathrm{c}} \pm 0.04$ & $0.99^{\mathrm{e}} \pm 0.18$ & $0.93^{\mathrm{c}} \pm 0.05$ \\
Evenness & Medium & $0.95^{\mathrm{c}} \pm 0.08$ & $0.96^{\mathrm{e}} \pm 0.10$ & $0.92^{\mathrm{c}} \pm 0.21$ \\
& Far & $0.91^{\mathrm{c}} \pm 0.22$ & $0.90^{\mathrm{e}} \pm 0.22$ & $0.89^{\mathrm{c}} \pm 0.22$ \\
& Overall mean & $0.93 \pm 0.11$ & $0.95 \pm 0.17$ & $0.91 \pm 0.16$ \\
& & $\mathrm{P}=0.58, \mathrm{~F}=0.54$ & $\mathrm{P}=0.3, \mathrm{~F}=1.22$ & $\mathrm{P}=0.83, \mathrm{~F}=0.17$ \\
\hline
\end{tabular}

Note: Single different letters on mean value indicate that there is significance difference at $(\mathrm{p}<0.05)$ between distances of farmland from residences of household in column whereas similar letters in column indicates that non- significant difference at $(\mathrm{p}>0.05)$.

\section{Effect of distance of farmland from homesteads on woody species richness and abundance}

As shown in the table 6, the woody species richness and abundance in the farmlands of near distance from residence is significantly higher than medium and far distance farmlands ( $p>0.05)$. This is because of woody trees planted and retained near to house is easily managed and protected buy all household members and trees present in farthest from their homesteads are cut by thieves at night. The farmer mentioned that theft as the major constraint for tree planting at far distance from homesteads. This finding was in line with Kidane \& Tesfaye (2006) who stated that theft was the major constraint tree planting on farmlands as an agroforestry practice. The trees far away from homesteads would be susceptible to low survival rates because of livestock grazing. This is in agreement with the findings of Duguma \& Hager (2010) who reported higher species richness and abundance of farmland trees retained in short distance from home in the central highlands of Ethiopia. The finding is also supported by Berhanu et al. (2004), Amaha et al. (2009), Woldu \& Aynekulu (2013), Abebe et al. (2014) who reported that more tree species in home compounds and fences than far away from homesteads due to day to day management and supervision by farmers.

Table 6. Mean species richness and abundance of woody species among the three distance categories from household's residence.

\begin{tabular}{lllll}
\hline & Distance & Woynima Workima & $\begin{array}{l}\text { Mankusa } \\
\text { Abdogema }\end{array}$ & $\begin{array}{l}\text { Yeraber } \\
\text { Girgriya }\end{array}$ \\
\hline Species & Near & $5.76^{\mathrm{a}} \pm 4.97$ & $5.86^{\mathrm{a}} \pm 1.88$ & $5.10^{\mathrm{a}} \pm 2.23$ \\
Richness & Medium & $3.71^{\mathrm{b}} \pm 1.73$ & $4.33^{\mathrm{b}} \pm 1.20$ & $3.33^{\mathrm{b}} \pm 1.30$ \\
& Far & $2.90^{\mathrm{b}} \pm 0.83$ & $2.95^{\mathrm{c}} \pm 0.85$ & $2.33^{\mathrm{b}} \pm 0.79$ \\
& Overall mean & $4.05 \pm 2.51$ & $4.38 \pm 1.31$ & $3.58 \pm 1.44$ \\
& & $\mathrm{P}<0.001, \mathrm{~F}=19.53$ & $\mathrm{P}<0.001, \mathrm{~F}=23.71$ & $\mathrm{P}<0.001, \mathrm{~F}=16.74$ \\
Species & Near & $9.95^{\mathrm{a}} \pm 4.53$ & $10.14^{\mathrm{a}} \pm 4.63$ & $7.71^{\mathrm{a}} \pm 3.47$ \\
Abundance & Medium & $4.81^{\mathrm{b}} \pm 2.06$ & $5.90^{\mathrm{b}} \pm 2.53$ & $3.90^{\mathrm{b}} \pm 1.79$ \\
& Far & $3.90^{\mathrm{b}} \pm 2.27$ & $3.67^{\mathrm{b}} \pm 1.46$ & $2.52^{\mathrm{b}} \pm 0.87$ \\
& Overall mean & $6.22 \pm 2.95$ & $6.57 \pm 2.87$ & $4.71 \pm 2.04$ \\
& & $\mathrm{P}<0.001, \mathrm{~F}=22.34$ & $\mathrm{P}<0.001, \mathrm{~F}=22.75$ & $\mathrm{P}<0.001, \mathrm{~F}=28.51$ \\
\hline
\end{tabular}

Note: Single different letters on mean values of richness and abundance in column indicates that significant difference at $(\mathrm{p}<0.05)$ whereas similar letters indicates that non-significant at $(\mathrm{p}>0.05)$.

Importance of maintaining woody species in the study area

Woody species serve a wide range of purposes for farming families in the study area. Respondents mentioned that woody species have diverse benefits in the study sites like soil fertility, animal fodder, bee forage, timber, firewood, fruit, cash income, farm tool, house construction, charcoal, local beer production, fencing and farm tool purposes. The respondents from study area reported that the major benefits of tree species in the study area are soil fertility (35.14\%), followed by firewood (24.54\%), timber production (11.66\%), 
fencing (8.44\%), animal fodder (4.55\%), fruit (4.50\%), income generation (4.28\%), house construction $(2.61 \%)$, charcoal production (1.61\%) and other purposes (Fig. 2).

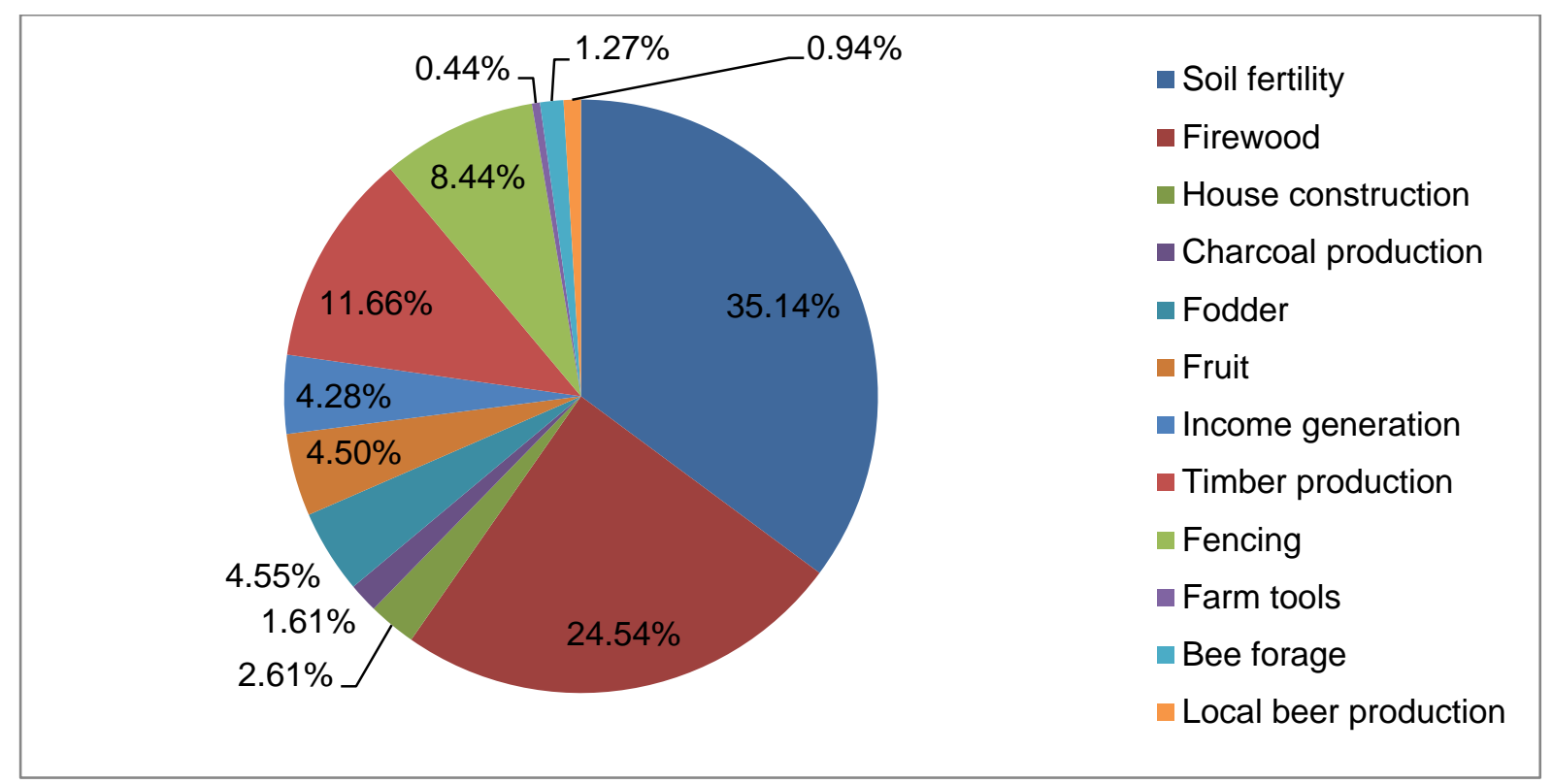

Figure 2. Farmers' reasons for retaining/ planting woody species in the study area.

Atta-Krah et al. (2004) confirmed that farmers actively planting or managing trees on their farms can be seen as an indicator of the fact that they appreciate trees in their farming systems. The present result is supported by Abebe (2005) who reported that on-farm trees can be used for multiple purposes viz. firewood, timber, wood (local construction, farm implements and household utensils), fodder, food, medicine, and they also play beneficial ecological roles such as erosion control and soil fertility improvement. Tefera et al. (2014) also reported that woody plants on farmland are used for multiple purposes such as fodder, construction materials, farm tools and equipment, sources of income, soil fertility, furniture and bee forage at Debark district in the northern highlands of Ethiopia.

\section{CONCLUSION}

Conserving biodiversity through nature reserves and other protected areas is an important step which are practiced by many countries but it is not sufficient to solve the problem of biodiversity loss. The role of biological diversity for ecosystem functions is not limited to protected areas. The result of the present study confirms that the farmlands can play a significant role in the conservation of native woody species. Moreover, the presence of woody species in these farmlands may favor the survival of other organisms and hence contribute to wider conservation of biological diversity. The woody species in the farmlands can also satisfy farmers' need of wood products. By doing so, they might also indirectly contribute to the conservation of biodiversity through reducing the pressure on natural forest otherwise could result in loss of natural forest cover and protected forests. In order to manage on-farm tree planting and sustain the existing indigenous woody species of which some are threatened species, it is necessary that more concerted efforts and investments are required to plant and retain woody species on farmlands to increase diversity. In order to make the existing agroforestry systems more successful through enhancing agricultural productivity sustainably and as trees with crops (on-farm planting) play a great role for both environment and economic development, there is a need to use extension system to convince local farmers and to create awareness about planting and managing of multipurpose and nitrogen fixing trees.

\section{ACKNOWLEDGEMENTS}

Authors would like to thank College of Dryland Agriculture and Natural Resource of Mekelle University, Mekelle for facilitating required resources for field work through Ministry of Education, Federal Democratic Republic of Ethiopia.

\section{REFERENCES}

Abebe T (2005) Diversity in Homegarden Agroforestry Systems of Southern Ethiopia, (Ph.D. Thesis).

Wageningen University and Research Centre, The Netherlands. 
Abebe T, Negatu W, Brouwer R \& Zaag P (2014) Understanding soil conservation decision of farmers in the Gedeb watershed, Ethiopia. Land Degradation \& Development 25(1): 71-79.

Aklilu A, Belayneh A, Alemayehu W, Kiros MH Ermias A \& Jeremias M (2013) Agroforestry practices and farmers' perception in koga watershed, Upper Blue Nile Basin, Ethiopia. Agriculture and Forestry 59(3): 75-89.

Aleman JC, Jarzyna MA \& Staver AC (2018) Forest extent and deforestation in tropical Africa since 1900. Nature Ecology \& Evolutionent 2: 26-33.

Alemayehu L \& Hager H (2010) Woody plants diversity and possession, and their future prospects in smallscale tree and shrub growing in agricultural landscapes in central highlands of Ethiopia. Small-scale Forestry 9(2): 153-174.

Alemu M (2009) Tenure security, resource endowments, and tree growing: evidence from the Amhara region of Ethiopia. Land Economics 85(2): 292-307.

Amaha K, Snyman HA \& Smit GN (2009) Soil seed bank evaluation along a degradation gradient in arid rangelands of the Somali region, eastern Ethiopia. Agriculture, Ecosystems \& Environment 129(4): 428-436.

Asfaw Z \& Hulten H (2003) Tree diversity management in the traditional agroforestry land-use of Sidama, southern Ethiopia. Acta Universitatis Agriculturae SLU SILVESTRIA 263(1): 1-28.

Asfaw Z (2010) Water Resources Management in Ethiopia: Implications for the Nile Basin. In: Hydrological and Related Aspects of Deforestation and Degradation of Woody Vegetation. Cambria Press.

Asfaw Z (2016) Woody Species Diversity and Structure of Agroforestry and Adjacent Land Uses in Dallo Mena District, South-East Ethiopia. Natural Resources 7(10): 515-534.

Atta-Krah K, Kindt R, Skilton JN \& Amaral W (2004) Managing biological and genetic diversity in tropical agroforestry. In: New Vistas in Agroforestry. Springer, Dordrecht, pp. 183-194.

Berhanu G, Pender J \& Tesfay G (2004) Collective action for grazing land management in crop-livestock mixed systems in the highlands of northern Ethiopia. Agricultural Systems 82(3): 273-290.

Boffa JM, Kindt R, Katumba B, Jourget JG \& Turyomurugyendo L (2008) Management of tree diversity in agricultural landscapes around Mabira Forest Reserve, Uganda. African Journal of Ecology 46(1): 24-32.

Crowley EL (1997) Rapid data collection using wealth ranking and other techniques (No.16). International Centre for Research in Agroforestry (ICRAF), Nairobi, Kenya.

Duguma LA \& Hager H (2010) Woody plants diversity and possession, and their future prospects in small-scale tree and shrub growing in agricultural landscapes in central highlands of Ethiopia. Small-scale Forestry 9(2): 153-174.

FAO (Food and Agriculture Organization) (2010) Global Forest Resources Assessment 2010 - Country Report Ethiopia. FAO, Rome.

FAO (Food and Agriculture Organization) (2011) State of the World's Forest-2011. FAO, Rome.

Felix GF, Diedhiou I, Garff ML \& Tittonell P (2018) Use and management of biodiversity by smallholder farmers in semi-arid West Africa. Global Food Security 18: 76-85.

Feyera S, Teketay D \& Näslund BA (2002) Native woody species regeneration in exotic tree plantations at Munessa-Shashemene Forest, southern Ethiopia. New Forests 24(2): 131-145.

Guyassa E, Raj AJ, Gidey K \& Tadesse A (2014) Domestication of indigenous fruit and fodder trees/ shrubs in dryland agroforestry and its implication on food security. International Journal of Ecosystem 4(2): 83-88.

Hedberg I, Edwards S \& Nemomissa S (2003) Flora of Ethiopia and Eritrea, Vol. 4/1. Addis Ababa University, Addis Ababa, Ethiopia.

Hoekstra DA, Torquebiau E \& Bishaw B (1990) Agroforestry: potentials and research needs for the Ethiopian highlands (No. 21). International Centre for Research in Agroforestry (ICRAF), Nairobi, Kenya.

Jarvis DI, Myer L, Klemick H, Guarino L, Smale L, Brown AHD, Sadiki M, Sthapit Br \& Hodgkin T (2000) A training guide for in situ conservation on-farm. version I, IPGRI, Rome.

Jose S (2009) Agroforestry for ecosystem services and environmental benefits: an overview. Agroforestry systems 76(1): 1-10.

JWARDO (Jabitehinan Woreda Agriculture and Rural Development Office) (2016) Jabitehinan Woreda. Agriculture and Rural Development Office, Annual Report Jabitehinan, Ethiopia.

Kidane B \& Tesfaye A (2006) Agroforestry practices and tree planting constraints and opportunities in Sekota district of the Amhara Regional State. Journal of the Drylands 1(1): 52-63.

Kindt R, Simons AJ \& Van Damme P (2004) Do farm characteristics explain differences in tree species diversity among Western Kenyan farms? Agroforestry Systems 63(1): 63-74. 
Kothari CR (2004) Research methodology: Methods and techniques. New Age International Publishers, New Delhi, India.

Mahari A (2014) Leaf Litter Decomposition and Nutrient Release form Cordia Africana Lam. and Croton Macrostachyus Del. Tree Species. Journal of Environment and earth Science 4(15): 1-7.

Mekonnen K (2001) Practices, Constraints and Agroforestry. Ethiopian Journal of Natural Resources 3(1): 161-178.

Mengistu F \& Hager H (2010) Integration of indigenous wild woody perennial edible fruit bearing species in the agricultural landscapes of Amhara region, Ethiopia. Agroforestry systems 78(1): 79-95.

MoME (Ministry of Mines and Energy) (2003) Geological Survey of Ethiopia: Industrial Minerals and Rocks Resource Potentials of Ethiopia. Ministry of Mines and Energy (MoME), Addis Ababa, Ethiopia.

Neba NE (2009) Management of woody plants in indigenous land use systems of the Sahel: example of north Cameroon. International NGO Journal 4(11): 480-490.

Negash M (2007) Trees management and livelihoods in Gedeo's agroforests, Ethiopia. Forests, Trees and Livelihoods 17(2): 157-168.

Pielou EC (1966) The measurement of diversity in different types of biological collections. Journal of Theoretical Biology 13: 131-144.

Shannon CE \& Weiner W (1963) The Mathematical Theory of Communication. University of Illinois Press, Urbana.

Srinivasan S (2014) Extension of deforestation in Ethiopia. International Journal of Economic and Business Review 2(2): 1-7.

Tabuti JR (2012) Important woody plant species, their management and conservation status in Balawoli Subcounty, Uganda. Ethnobotany Research and Applications 10: 269-286.

Tefera B, Ruelle ML, Asfaw Z \& Tsegay BA (2014) Woody plant diversity in an Afromontane agricultural landscape (Debark District, northern Ethiopia). Forests, Trees and Livelihoods 23(4): 261-279.

Teketay D (2001) Deforestation, wood famine, and environmental degradation in Ethiopia's highland ecosystems: urgent need for action. Northeast African Studies 8(1): 53-76.

Tesfay A, Wiersum KF \& Bongers F (2010) Spatial and temporal variation in crop diversity in agroforestry homegardens of southern Ethiopia. Agroforestry systems 78(3): 309-322.

Woldu M \& Aynekulu E (2013). Exclosures land management for restoration of the soils in degraded communal grazing lands in northern Ethiopia. Land Degradation \& Development 24(6): 528-538.

Zebene G, Alemu M, Menale K \& Köhlin G (2010) Household tree planting in Tigrai, Northern Ethiopia: Tree species, purposes, and determinants. EfD Discussion Paper 10.

Zerihun G (2002) How successful the agricultural development led industrialization strategy (ADLI) will be by leaving the existing landholding system intact? Economic Focus 4(4): 16-20. 